\title{
Study on the Influence of Rural Financial Development on Farmers' Income Growth in Guizhou Province
}

\author{
Chenggang Li, Xiaoliang Liu, Mingguo Zhang, Lingyun Luo and Yandan Xue \\ Faculty of Finance, Guizhou University of Finance and Economics, Guiyang, 550025, China
}

Keywords: Rural finance; Farmers' income; Multiple regression model

\begin{abstract}
With the development of rural finance in Guizhou Province, China, the farmers' income in Guizhou Province has been growing. To study the influence of rural financial development on farmers' income growth in Guizhou Province is beneficial to promote the development of rural finance in Guizhou Province and improve the farmers' income. Using multiple regression model, this paper empirically analyzes the impact of rural financial development on farmers' income growth in Guizhou Province. The empirical results show that the rural financial development has a positive impact on the income of farmers. Among them, the efficiency and scale of rural finance has a significant impact on the farmers' income, but the structure of rural finance has no significant impact on the farmers' income.
\end{abstract}

\section{Introduction}

Guizhou's rural economic development has changed a lot in the 30 years of China's reforming and opening up. In 1978, the per capital income of rural households in Guizhou Province was only 109.3 yuan. By 2014, the annual income of rural households in Guizhou Province reached 6671 yuan, which is 61.03 times more than that in 1978. Although from the point of view of the longitudinal comparison, the overall GDP of Guizhou Province and farmer's annual income have been significantly improved. But compared Guizhou Province with other provinces, there is still a huge gap between farmers' income and the national average of Guizhou Province and that of other provinces. At the same time, the rural finance in Guizhou Province has been greatly developed and promotes the growth of farmers' income. To study the influence of rural financial development on farmers' income growth in Guizhou Province is beneficial to promote the development of rural finance in Guizhou Province and improve the income of farmers.

The structure of this paper are as follows: the second part is the literature review and the related research achievements are reviewed; the third part is the empirical study, in which the rural financial development on farmers' income growth are analyzed; the fourth part is the conclusion and policy recommendations, in which sums up the research results of this paper and proposes relevant policy recommendations.

\section{Literature Review}

Many scholars have made a deep research on the impact of rural financial development on farmers' income. From the perspective of financial development, Greenwood and Boyan (1990) directly discuss the relationship between financial development and income distribution, and find that in the early stages, financial development promotes economic growth, while it has expanded the income gap. With economic growth, this gap will be gradually reduced. Jeanneney and Kpodar's (2005) research results show that the financial development can promote the low incomes' income, but non-normal fluctuations of financial markets easily bring negative effect on low income groups. Even the negative effect is more than the positive effect of financial development. Liu (2007) aims to identify the real relationships between the rural financial development and farmer income growth in China over the period 1978-2004. The results show that the rural financial development has definitely negative effects on the peasants' growth. Some policy suggestions are put forward to promote the peasants' income growth through the rural financial development. Qian and Zhou (2011) study the mechanism of rural finance development to farmers' income growth in China. The results 
show that rural physical capital investment, rural human capital, rural labors transfer has remarkable relevance with farmers' income; rural finance scale and rural finance structure and rural physical capital investment, rural human capital, rural labors transfer are being related, but rural finance efficiency and rural physical capital investment, rural human capital, rural labors transfer actually have the negative relations. $\mathrm{Li}$ and Ye (2014) conduct an empirical analysis of the influence of the scale, efficiency and structure of rural financial development and the distribution density of rural financial resources on the increase of farmers' income. The results show that only the increase of loan-to-deposit ratio of rural financial institutions and the increase of the number of practitioners in rural financial institutions per ten thousand people can play a significant role in promoting the increase of farmers' income. Based on theoretical derivation and national statistical data of 2004-2013, Liang and Zhang (2016) study the influence of urban-rural integration, rural logistics and rural finance on the income of farmers. The results show that the rural logistics and rural finance have a significant impact on the farmers' income. The urban-rural integration plays its role through the intermediary effect of rural logistics and rural finance, and the integration of the three factors increases the farmers' income.

From the above research results, we can see that there is a significant correlation between the rural financial development and the income of farmers. The rural financial development has a great impact on the income of farmers. This paper chooses China's Guizhou Province as the research object, and discusses the influence of the rural financial development on farmers' income growth in Guizhou Province. In the end, this paper puts forward some policy suggestions for rural financial development and farmers' income growth in Guizhou Province.

\section{Empirical Study}

Model Design. Combining with the related references and the present situation of the rural finance of Guizhou Province, this paper selects the natural logarithm of the income of the farmers (FR) as the dependent variable. This paper selects the rural financial development efficiency indicator (RLD), scale indicator (RFIR) and structural indicators (RLTL) as independent variables. Rural human capital (HC), industrial structure in countryside (INS) and rural investment (RFI) are selected as the control variables. We establish the model of the impact of the rural financial development in Guizhou Province on the income of the farmers, as shown below:

$$
F R_{t}=\alpha_{0}+\alpha_{1} R L D_{t}+\alpha_{2} R F I R_{t}+\alpha_{3} R L T L_{t}+\alpha_{4} H C_{t}+\alpha_{5} I N S_{t}+\alpha_{6} R F I_{t}+\mu_{t}
$$

In this mathematical model, FR is the annual income of farmers in Guizhou Province, $\mu$ is a random error term.

Data Sources and Processing. The data used in this paper comes from Guizhou Province Bureau of Statistics and the "Guizhou Statistical Yearbook". The data samples span is from 2000 to 2014. The related data mainly includes two parts, which are the farmers' income and the rural financial development. In order to reduce the volatility of the data, this paper makes a logarithmic treatment of the above variables.

Unit Root Test. Unit root test is to test whether there is a unit root in the time series. If there is a unit root in the time series, the time series is a non-stationary time series. Then modeling the time series will lead to the "pseudo regression" phenomenon. Therefore, when modeling the time series, it is the first to test whether there is a unit root in the time series.

There are many methods to do unit root test, such as DF test, ADF test, PP test, KPSS test and other methods (). This paper uses ADF test to do the unit root test of the above variables. Test results are shown in Table 1. From the Table 1, we can find that the ADF value of all the variables is larger than the critical value. Therefore, all the variables are stationary sequence. 
Table 1 Unit root test results of the variables

\begin{tabular}{|c|c|c|c|c|c|c|c|}
\hline \multirow{2}{*}{$\begin{array}{c}\text { Variable } \\
\text { s }\end{array}$} & \multirow{2}{*}{$\begin{array}{l}\text { Test } \\
\text { type }\end{array}$} & \multirow{2}{*}{$\begin{array}{c}\text { ADF } \\
\text { statistic } \\
\text { value }\end{array}$} & \multicolumn{3}{|c|}{ Critical value } & \multirow[t]{2}{*}{ P-value } & \multirow{2}{*}{$\begin{array}{c}\text { Conclusio } \\
\mathrm{n}\end{array}$} \\
\hline & & & $1 \%$ & $5 \%$ & $10 \%$ & & \\
\hline FR & $\begin{array}{c}(0,1,0 \\
)\end{array}$ & -4.7854 & -4.2970 & $\begin{array}{c}-3.212 \\
6\end{array}$ & -2.7476 & 0.0098 & stable \\
\hline RLD & $\begin{array}{c}(1,1,0 \\
)^{2}\end{array}$ & -4.9075 & -4.8034 & $\begin{array}{c}-3.212 \\
9\end{array}$ & -2.7476 & 0.0095 & stable \\
\hline RFIR & $\begin{array}{c}(0,1,1 \\
)\end{array}$ & -4.5852 & -4.4205 & $\begin{array}{c}-3.259 \\
8\end{array}$ & -2.7722 & 0.0086 & stable \\
\hline RLTL & $\begin{array}{c}(0,1,0 \\
)\end{array}$ & -4.3756 & -4.2970 & $\begin{array}{c}-3.212 \\
2\end{array}$ & -2.7476 & 0.0065 & stable \\
\hline $\mathrm{HC}$ & $\begin{array}{c}(0,1,0 \\
)\end{array}$ & -4.3425 & -4.2970 & $\begin{array}{c}-3.212 \\
9\end{array}$ & -2.7476 & 0.0072 & stable \\
\hline INS & $\begin{array}{c}(0,1,0 \\
)\end{array}$ & -4.3745 & -4.2970 & $\begin{array}{c}-3.212 \\
6\end{array}$ & -2.7476 & 0.0082 & stable \\
\hline RFI & $\begin{array}{c}(0,1,0 \\
)\end{array}$ & -4.3451 & -4.2970 & $\begin{array}{c}-3.212 \\
6\end{array}$ & -2.7716 & 0.0092 & stable \\
\hline
\end{tabular}

Empirical Result Analysis. The parameters of the model (1) are estimated. The estimation results are shown in Table 2:

Table 2 Estimation results

\begin{tabular}{|c|c|c|c|c|}
\hline Variable & Coefficient & Standard deviation & $\begin{array}{c}\text { t-statisti } \\
\text { c }\end{array}$ & $\begin{array}{c}\text { Adjoint } \\
\text { probability }\end{array}$ \\
\hline $\mathrm{C}$ & -0.0032 & 0.0270 & -0.1188 & 0.9055 \\
\hline RLD & 0.0238 & 0.0098 & 2.4392 & 0.0150 \\
\hline RFIR & 0.0128 & 0.0056 & 2.3053 & 0.0214 \\
\hline RLTL & 0.0199 & 0.0359 & 0.5561 & 0.5783 \\
\hline $\mathrm{HC}$ & 0.0019 & 0.0152 & 0.1246 & 0.9009 \\
\hline INS & 0.0064 & 0.0049 & 1.3252 & 0.0055 \\
\hline RFI & 0.0071 & 0.0181 & 0.3898 & 0.6968 \\
\hline R-squared & 0.8313 & $\begin{array}{l}\text { Mean dependent } \\
\text { var }\end{array}$ & \multicolumn{2}{|r|}{-0.0006} \\
\hline $\begin{array}{l}\text { Adjusted } \\
\text { R-squared }\end{array}$ & 0.8232 & $\begin{array}{l}\text { S.D. dependent } \\
\text { var }\end{array}$ & \multicolumn{2}{|r|}{0.0216} \\
\hline S.E. of regression & 0.0214 & $\begin{array}{l}\text { Akaike info } \\
\text { criterion }\end{array}$ & \multicolumn{2}{|r|}{-4.8443} \\
\hline Sum squared resid & 0.3306 & Schwarz criterion & \multicolumn{2}{|r|}{-4.8003} \\
\hline Log likelihood & 1777.5850 & $\begin{array}{l}\text { Hannan-Quinn } \\
\text { criter. }\end{array}$ & \multicolumn{2}{|r|}{-4.8273} \\
\hline F-statistic & 3.8947 & $\begin{array}{l}\text { Durbin-Watson } \\
\text { stat }\end{array}$ & \multicolumn{2}{|r|}{2.0432} \\
\hline Prob(F-statistic) & 0.0008 & & & \\
\hline
\end{tabular}

From the results of Table 2, we can see that R-squared $=0.8313$ and Adjusted R-squared $=$ 0.8232. This indicates that the fitness of the regression model is good. The F-statistic value of the regression model is 3.8947 , and the probability of the regression model is 0.0008 . So, the regression 
model is significant. The Durbin-Watson value of the regression model is 2.0432 , which is close to 2. Therefore, it can be considered that there is no multicolinearity.

Seen from the coefficients of the efficiency of the rural financial development indicator (RLD), scale indicator (RFIR) and structural indicator (RLTL) were $0.238,0.0128$ and 0.0199 , respectively. The coefficients are plus. This shows that rural financial development have a positive impact on the income of the farmers. Among them, the probability of the efficiency index (RLD) and the scale index (RFIR) is 0.0150 and 0.0214 . Both of them are less than $5 \%$, which shows that the efficiency and the scale of rural finance have a significant impact on farmers' income. The probability of the structural index (RLTL) was 0.5783, which was greater than 5\%. This result indicates that the structure of rural finance has no significant effect on the income of farmers.

\section{Conclusions and Policy Recommendations}

In this paper, we use the data of rural finance development and farmers' income during 2000 - 2014 of Guizhou Province, China. We construct a multiple regression model, and empirically analyze of the impact of the rural financial development in Guizhou Province on the growth of farmers' income. The empirical results show that the indicators of rural financial development (efficiency, scale and structural indicators) are positive. This indicates that the rural financial development have a positive impact on farmers' income. Among them, the efficiency and the scale of rural finance have a significant impact on the income of farmers. But the structure of rural finance has no significant impact on the income of farmers.

According to the conclusion of this paper, we put forward the following policy recommendations:

Firstly, improve the rural financial service system in Guizhou Province. Unremittingly deepen the rural financial system reform, promote the development of the rural economy and financial development, improve the rural credit system, use the way of the guidance and supervision to let farmers make good use of loan, promote the production, and improve their income.

Secondly, improve the policy of the rural financial development in Guizhou Province. According to specifications of rural financial development, make the standardization of the rural financial management and service. Support the long-term policy of the rural financial reform and development, and the legalization of rural finance. Establish differentiated supervision policy for the state-owned commercial banks, policy banks, joint-stock commercial banks, cooperative banks and rural financial institutions to make sure they provide good rural financial services to the farmers.

Thirdly, improve the rural financial development environment. Guizhou Province government and relevant departments participate and promote the rural financial ecological environment construction, strengthen the rural credit system construction, financial literacy, and financial talent education, so as to improve the investment environment of farmers and increase farmers per capital income.

\section{References}

[1] J. Greenwood, J. Boyan. Financial Development. Growth, and the Distribution of Income. Journal of Political Economy, 1990, 98(5): 1076-1107.

[2] S.G. Jeanneney, K. Kpodar. Financial Development, Financial Instability and Poverty[R]. Québec: CSAE Working Paper Series, 2005.

[3] D. Liu. Practical An analysis of Rural Financial Development Efficiency and Peasants' Income Growth [J]. Journal of ShanXi Finance and Economics University, 2007, 29(1): 44-49.

[4] T. Qian, Y. Zhou. Study on the Mechanism of Rural Financial Development Affecting the Growth of Farmers' Income [J]. Financial Theory \& Practice, 2011, (4): 57-62.

[5] X. Li, H. Ye. An Empirical Study of China's Rural Financial Development and Farmer's 
Income Growth [J]. Journal of Jiangxi University of Finance and Economics, 2014, (4): 88-97.

[6] W. Liang, W. Zhang. The Impact of Urban-Rural Integration Rural Logistics and Rural Finance on the Income of Farmers [J]. Journal of Beijing Jiaotong University (Social Sciences Edition), 2016, 15(1): 98-105.

[7] T.Gao. Econometric Analysis Methods and Modeling: Eviews Application and Examples (Second Edition) [M]. Beijing: Tsinghua University Press, 2009: 166-173.

[8] C. Hou, X. Xu. Time Series Analysis of Econometric Methods [J]. Technology Economy, 2010, 29(8): 51-57. 